\title{
Augmentation of Fibroblast Proliferation by Bleomycin
}

\author{
Pope L. Moseley, Christine Hemken, and Gary W. Hunninghake \\ Pulmonary Division, Department of Internal Medicine, Veterans Administration Hospital and \\ University of Iowa College of Medicine, Iowa City, Iowa 52242
}

\begin{abstract}
Bleomycin-induced lung disease is characterized by fibroblast proliferation and pulmonary fibrosis. In these studies, we demonstrate that fibroblasts are relatively resistant to clinically relevant amounts (below $10^{-4} \mathrm{U} / \mathrm{ml}$ ) of bleomycin and that these levels of bleomycin augment fibroblast proliferation in response to various fibroblast growth factors. These observations suggest that one mechanism by which bleomycin causes pulmonary fibrosis is augmentation of fibroblast proliferation.
\end{abstract}

\section{Introduction}

Bleomycin, a chemotherapeutic agent useful in the treatment of testicular carcinoma, lymphoma, and squamous cell carcinomas, is known to produce lung parenchymal injury and interstitial fibrosis in man and in animal models (1-3). The development of lung disease is the major limiting side effect of this drug. Histologic studies of human lung (1) and various animal models (4-7) of the disease have demonstrated evidence of injury to a variety of lung cells, including a denuding of the vascular basement membrane. This injury is also associated with aggregation of platelets, evidence of fibroblast proliferation, and the development of fibrosis. The latter observation suggests that fibroblasts are relatively resistant to the cytotoxic effects of bleomycin. In these studies, we present data that not only suggest that fibroblasts are relatively resistant to bleomycin-induced injury compared with endothelial cells, but also that bleomycin at or below peak therapeutic serum levels augments fibroblast proliferation in response to known platelet-derived growth factors (8-9).

\section{Methods}

Cell cultures. Human umbilical vein endothelial cells were isolated from fresh umbilical cords after exposure to type I collagenase $(1 \mathrm{mg} / \mathrm{ml}$ for $8 \mathrm{~min}$; Cooper Biomedical Co., Malvern, PA) as described by Johnson et al. (10). The cells were washed and then resuspended in medium 199 (M-199;' Gibco, Grand Island, NY) plus 10\% fetal calf serum, endothelial cell growth supplement $(75 \mathrm{mg} /$ liter; Collaborative Research, Inc., Waltham, MA), bovine sodium heparin ( $150 \mathrm{U} / \mathrm{ml}$; Elkins-Sinn, Inc., Cherry

Address correspondence to Pope L. Moseley, M.D., Department of Internal Medicine, Room E324-1 GH, University of Iowa Hospitals and Clinics, Iowa City, IA 52242.

Received for publication 16 October 1985 and in revised form 24 July 1986.

1. Abbreviations used in this paper: FGF, fibroblast growth factor; HFL1, human lung fibroblast; LDH, lactate dehydrogenase; $M-199$, medium 199; PDGF, platelet-derived growth factor; $\mathrm{PGE}_{2}$, prostaglandin $\mathrm{E}_{2} ; \mathrm{PS}$, platelet supernatant.

The Journal of Clinical Investigation, Inc.

Volume 78, November 1986, 1150-1154
Hill, NJ), and placed into tissue culture plates at a density of $2 \times 10^{5}$ cells $/ \mathrm{ml}$. After the cells reached confluence, they were removed from the plates and again placed into culture at the same initial cell density as described above. Only passages 1-2 were used. Greater than $99 \%$ of the endothelial cells in these cultures expressed Factor VIII-related antigen on their surface (data not shown). Normal diploid human lung fibroblasts (HFL-1) were obtained from American Type Culture Collection, Rockville, MD. Only passages 10-15 were used. Fibroblasts were also obtained from fetal lung. These fetal lung fibroblasts were isolated following the methods of Bradley et al. (11) by exposing the tissue to trypsin. Passages 10-12 were used. For the cytotoxicity assays, both types of fibroblasts were grown in M-199 plus 10\% fetal calf serum, endothelial cell growth supplement, and bovine heparin for the endothelial cells, as described above.

Cytotoxicity assay. The cytotoxicity assay was performed using cultured fibroblasts and endothelial cells. For each assay, the desired target cells were placed into 24-well tissue culture plates. When the cells reached confluence, $\left[{ }^{3} \mathrm{H}\right]$ uridine $\left(4 \times 10^{-1} \mu \mathrm{Ci} /\right.$ well; New England Nuclear, Boston, MA) was added to each well. The plate was then incubated for 24 h at $37^{\circ} \mathrm{C}$ in a $5 \% \mathrm{CO}_{2}$ atmosphere. The cells were then washed extensively with Hanks' balanced salt solution (HBSS). Medium with $10 \%$ fetal calf serum, with or without various amounts of bleomycin, was then added to the cells. The cells were incubated for $24 \mathrm{~h}$ in a $5 \% \mathrm{CO}_{2}$ atmosphere at $37^{\circ} \mathrm{C}$. At the end of the incubation, $0.5 \mathrm{ml}$ of the cell supernatant was removed from each well and placed into a scintillation vial. In order to lyse the cells, $0.4 \mathrm{ml}$ of $0.25 \mathrm{~N} \mathrm{NaOH}$ was added to the remaining $0.5 \mathrm{ml}$ of supernatant and cells. The solution was neutralized with $0.1 \mathrm{ml}$ of $1 \mathrm{~N} \mathrm{HCl}$. The lysed cells with their supernatants were then placed into a scintillation vial. The scintillation vials containing supernatants alone were also treated with $0.4 \mathrm{ml}$ of $0.25 \mathrm{~N} \mathrm{NaOH}$ and $0.1 \mathrm{ml}$ of $1 \mathrm{~N} \mathrm{HCl}$. The solution in each vial was mixed with $10 \mathrm{ml}$ of scintillation cocktail (Ready-Solv HP; Beckman Instruments, Inc., Fullerton, CA). The radioactivity in each vial was measured on a scintillation counter (LS 6800; Beckman Instruments, Inc.). Cell injury was expressed in terms of a cytotoxicity index:

$$
\frac{A-B}{C-B} \times 100 \text { where }
$$

Twice the dpm released from the vial containing the experimental $A=$ supernatant alone

Total dpm of the vial containing the experimental supernatant alone + the vial containing the remaining supernatant and experimental cells

Twice the dpm from the vial containing the control supernatant $B=$ alone

Total dpm of the vial containing the control supernatant alone + the vial containing the remaining supernatant and control cells

Twice the dpm for a vial containing the supernatant of cells exposed $C=$ to $3 \% \mathrm{H}_{2} \mathrm{O}_{2}$

Total dpm of the vial containing the supernatant of cells exposed to $3 \% \mathrm{H}_{2} \mathrm{O}_{2}$ + the vial containing the remaining supernatant and cells exposed to $3 \% \mathrm{H}_{2} \mathrm{O}_{2}$.

Thus, an index of $100 \%$ indicates the experimental preparation caused complete release of $\left[{ }^{3} \mathrm{H}\right]$ uridine from the cells, and an index of $0 \%$ indicates no release of $\left[{ }^{3} \mathrm{H}\right]$ uridine beyond a spontaneous leak during the culture period. In these studies, the spontaneous leak for both cell types 
was $<40 \%$. Prior studies in explanted lung tissue have demonstrated that there is a direct correlation between $\left[{ }^{3} \mathrm{H}\right]$ uridine release and lactate dehydrogenase (LDH) release in this assay (12). The release of LDH by isolated cells exposed to a range of bleomycin concentrations was also examined in the present study. In this study, the correlation between the release of $\mathrm{LDH}$ and $\left[{ }^{3} \mathrm{H}\right]$ uridine was highly significant $(r=0.886 ; P$ $<0.001$ ).

Platelet-derived growth factors. Erythrocyte free pooled human platelets were obtained from the University of Iowa Blood Bank and washed twice at $4^{\circ} \mathrm{C}$ in HBSS without calcium or magnesium. The platelets were then resuspended at a density of $10^{9} \mathrm{cells} / \mathrm{ml}$ in HBSS with calcium and magnesium and $45 \mathrm{U}$ of irradiated human thrombin (No. T-4393; Sigma Chemical Co., St. Louis, MO) was added. The platelets were then incubated at $37^{\circ} \mathrm{C}$ for $20 \mathrm{~min}$.

After aggregation, the platelets were centrifuged at $2,200 \mathrm{~g}$ for 15 min and the resulting supernatant (PS) was filtered through a $0.2-\mu \mathrm{m}$ filter (Millipore/Continental Water Systems, Bedford, MA) and stored at $-70^{\circ} \mathrm{C}$. This supernatant was utilized as a source of platelet-derived growth factors. In some instances, partially purified platelet-derived growth factor (PDGF), as well as fibroblast growth factor (FGF), were also utilized. Both FGF and PDGF were obtained from Collaborative Research, Inc.

Fibroblast growth factor assay. For these studies, fibroblasts were placed into 48-well flat-bottomed tissue culture plates at a low density of $4.0 \times 10^{4}$ cells $/ \mathrm{cm}^{2}$ in M-199 plus $0.4 \%$ fetal calf serum. Under these conditions, the cells attached to the plate and remained healthy but proliferated at a very slow rate. After $72 \mathrm{~h}$ in culture, the tissue culture medium was removed and replaced with the same medium containing various growth factors and/or amounts of bleomycin. For controls, the cells were also grown in M-199 plus $0.4 \%$ serum alone or M-199 plus optimal amounts (10\%) of serum. After an additional $72 \mathrm{~h}$ in culture the cells were pulsed with $\left[{ }^{3} \mathrm{H}\right]$ thymidine $\left(2.5 \times 10^{-3} \mu \mathrm{Ci} / \mathrm{ml}\right.$; NET-355; New England Nuclear, Boston, MA) for $4 \mathrm{~h}$ at $37^{\circ} \mathrm{C}$. The tissue culture medium was then removed and the cells were washed with $5 \%$ cold trichloroacetic acid. After washing, $0.4 \mathrm{ml}$ of $0.25 \mathrm{~N}$ sodium hydroxide was added to solubilize the cells; then $0.1 \mathrm{ml}$ of $1 \mathrm{~N}$ hydrochloric acid was added to neutralize the $\mathrm{NaOH}$. The liquid was then placed in a counting vial. $10 \mathrm{ml}$ of scintillation fluid (Ready Solv HP; Beckman Instruments, Inc.) was also added to the vials before counting in a scintillation counter. Incorporation of $\left[{ }^{3} \mathrm{H}\right]$ thymidine was used as an index of cell proliferation. These radioassay techniques of cell proliferation were confirmed by actual cell counts.

Statistics. Analysis of all dose response data was accomplished using a one-way analysis of variance. Significant differences between groups were assessed by Student's $t$ test.

\section{Results}

Bleomycin caused significant cell injury to both fibroblasts and endothelial cells in a dose-dependent manner (Fig. 1). There was significantly greater cytotoxicity for endothelial cells than for fibroblasts $(P<0.05)$. At doses of bleomycin that are normally achieved in plasma (below $10^{-4} \mathrm{U} / \mathrm{ml}$ ), no significant injury of fibroblasts could be detected.

As expected, PS (1:6 dilution) alone, PDGF (1 U/ml) alone, and FGF $(100 \mathrm{ng} / \mathrm{ml})$ alone caused a significant increase in $\mathrm{fi}$ broblast proliferation compared with control cultures $(0.4 \%$ serum alone; Fig. 2, $a-c$; each $P<0.05$ ). The addition of bleomycin at doses of $10^{-8} \mathrm{U} / \mathrm{ml}$ resulted in a further significant increase in fibroblast proliferation above that caused by the growth factors alone (Fig. 2, $a-c$ ). Human thrombin did not cause fibroblast proliferation either alone or in the presence of bleomycin (data not shown). Endotoxin also was not found to cause fibroblast proliferation (data not shown). There were no significant differences in the augmentation of proliferation of

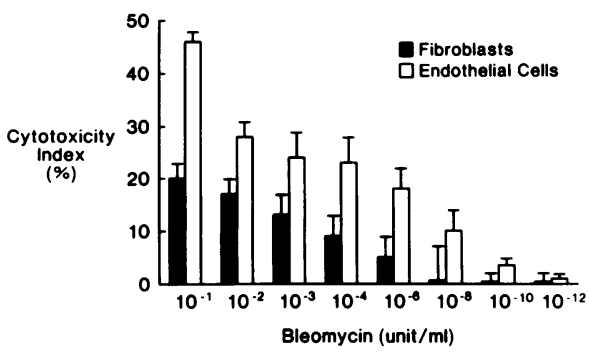

Figure 1. Bleomycin-induced injury to fibroblasts and endothelial cells. Human lung fibroblasts and human umbilical vein endothelial cells were plated and labeled with $\left[{ }^{3} \mathrm{H}\right]$ uridine and incubated with doses of bleomycin from $10^{-2} \mathrm{U} / \mathrm{ml}$ to $10^{-12} \mathrm{U} / \mathrm{ml}$ for $24 \mathrm{~h}$. Release of $\left[{ }^{3} \mathrm{H}\right]$ uridine into the supernatant was used as a measure of cell death and expressed as a cytotoxicity index (see text). The data represent the mean \pm SEM of four separate experiments.

HFL-1 fibroblasts compared with biopsy-derived fibroblasts in response to bleomycin (Fig. 3).

Because bleomycin is known to cleave DNA specifically at adenosine-thymidine bonds with liberation of free thymidine (13-15), actual cell counts by light microscopy were done as a check of the $\left[{ }^{3} \mathrm{H}\right]$ thymidine incorporation assay. These results revealed that $P S$ alone caused a significant increase in cell numbers from $13 \pm 2 \times 10^{4}$ cells $/ \mathrm{ml}$ to $27 \pm 1 \times 10^{4}$ cells $/ \mathrm{ml}$ (Fig. 4 ; $P<0.05)$. Bleomycin alone caused no increase in fibroblast proliferation above $0.4 \%$ serum alone, but bleomycin plus PS resulted in significant increases in proliferation over medium alone $\left(13 \pm 2 \times 10^{4}\right.$ cells $/ \mathrm{ml}$ vs. $36 \pm 2 \times 10^{4}$ cells $\left./ \mathrm{ml} ; P<0.05\right)$ and PS alone $\left(27 \pm 1 \times 10^{4}\right.$ cells $/ \mathrm{ml}$ vs. $36 \pm 2 \times 10^{4}$ cells $/ \mathrm{ml} ; P$ $<0.05$ ).

To study the dose-response effects of bleomycin on fibroblast proliferation, various amounts of bleomycin were added to PSexposed fibroblasts (Fig. 5). At very high doses $\left(10^{-2}-10^{-4}\right.$ $\mathrm{U} / \mathrm{ml}$ ), bleomycin inhibited the fibroblast growth response to PS to a level that was significantly less than PS alone $(P<0.05)$. In fact, fibroblast growth in the presence of the highest dose of bleomycin $\left(10^{-2} \mathrm{U} / \mathrm{ml}\right)$ plus PS was no different from that seen with $0.4 \%$ serum alone. As the amount of bleomycin decreased, there was an augmentation of the fibroblast growth response to PS with a maximal response at $10^{-8} \mathrm{U} / \mathrm{ml}$ of bleomycin $(P$ $<0.05$ ). Overall, there was a significant dose dependence of fibroblast proliferation in response to the combination of bleomycin and PS (Fig. 5; $P<0.05$ ).

\section{Discussion}

The present studies demonstrate that fibroblasts are less sensitive in vitro to bleomycin injury than endothelial cells and are only injured by relatively high doses of bleomycin. The observation that relatively high doses of bleomycin inhibit fibroblast proliferation is consistent with those of Absher et al. (16), who showed that exposure of fibroblasts to bleomycin at doses of $10^{-4} \mathrm{U} / \mathrm{ml}$ and above resulted in an inhibition of cell growth. Although the mechanism by which bleomycin injures cells was not evaluated in the present studies, prior studies have shown that bleomycin may cause cell injury by lipid peroxidation (17-18) and by DNAstrand nicking (19-20). At lower, clinically relevant concentrations, however, bleomycin appears to augment fibroblast proliferation in response to various fibroblast growth factors. Because prior studies have shown that bleomycin preferentially cleaves 

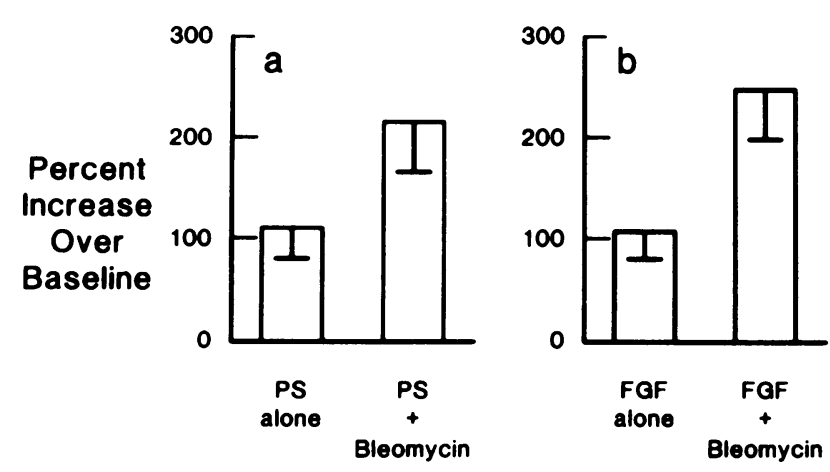

DNA at adenosine-thymidine bonds (13), the results of the standard $\left[{ }^{3} \mathrm{H}\right]$ thymidine incorporation assay were also confirmed by actual cell counts. These studies revealed that increases in fibroblast proliferation seen with the combination of bleomycin and PS were actual increases in cell numbers. In fact, there was very close agreement in the percent increase in fibroblast proliferation as determined by $\left[{ }^{3} \mathrm{H}\right]$ thymidine incorporation (133 $\pm 13 \%$ over PS alone) and by visual counts (136 $\pm 5 \%$ over PS alone).

At this time, the findings of this study can only be directly related to established fibroblast lines and may not be representative of human lung fibroblasts in vivo. These observations may be relevant, however, to the pathogenesis of bleomycin-induced lung fibrosis. Prior histologic studies and data from animal models (4-6) have shown that bleomycin-induced lung disease may be divided into various stages. Initially, injury occurs to endothelial cells. This is followed by denuding of the vascular basement membrane and the formation of platelet aggregates and microthrombi. Finally, there is fibrosis of the tissue from collagen accumulation, which is associated with an increase in fibroblast numbers. The present studies strongly suggest that

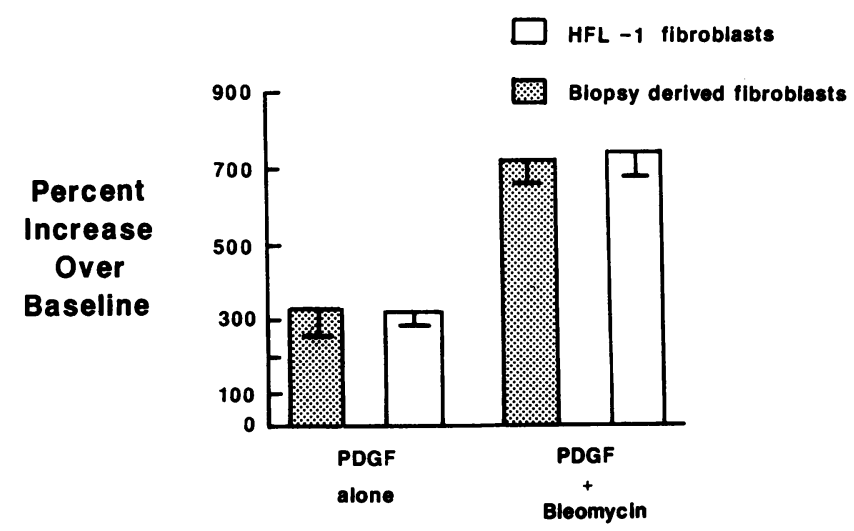

Figure 3. Proliferation of different fibroblast lines in response to purified PDGF. Commercially available HFL-1 and HFL-1 obtained by biopsy were exposed to PDGF ( $1 \mathrm{U} / \mathrm{ml}$ ) alone, or in combination with $10^{-8} \mathrm{U} / \mathrm{ml}$ bleomycin. At the end of incubation, the cells were pulsed with $\left[{ }^{3} \mathrm{H}\right]$ thymidine. The incorporation of $\left[{ }^{3} \mathrm{H}\right]$ thymidine was used as an index of cell proliferation. The data represent the mean \pm SEM of four separate experiments.
Figure 2. Fibroblast proliferation in response to various growth factors alone and to growth factors plus bleomycin. The fibroblasts were incubated with $(a)$ PS (1:6 dilution); (b) FGF (100 ng/ml); or (c) PDGF $(1 \mathrm{U} / \mathrm{ml})$ alone or in combination with $10^{-8}$ $\mathrm{U} / \mathrm{ml}$ of bleomycin. At the end of incubation, the cells were pulsed with $\left[{ }^{3} \mathrm{H}\right]$ thymidine. The incorporation of $\left[{ }^{3} \mathrm{H}\right]$ thymidine was used as an index of cell proliferation. Zero growth is equal to $\left[{ }^{3} \mathrm{H}\right]$ thymidine incorporation by cells incubated with $0.4 \%$ serum alone; actual disintegrations per minute for these controls varied from 1,000 to 1,500 . The data represent the mean \pm SEM of 10 separate experiments. bleomycin may play a role in lung fibrosis not only by causing cell injury but also by augmenting fibroblast proliferation in response to growth factors to which these cells are exposed as a result of injury to the endothelium. These factors likely include growth factors derived from aggregated platelets as well as other factors that may be present in serum $(8-9,21,22)$.

A precise mechanism for the augmentation of growth factorinduced fibroblast proliferation by bleomycin is not clear. Bleomycin may stimulate the fibroblast to generate a factor that augments fibroblast proliferation. Such a factor by itself would not cause fibroblast proliferation but would instead augment the response to another growth factor. Another mechanism by which bleomycin might augment the response to a growth factor is by blocking the generation of a suppressive factor produced by the fibroblast itself. It is known, for example, that fibroblasts produce prostaglandin $\mathrm{E}_{2}\left(\mathrm{PGE}_{2}\right)$, which functions to suppress cell growth (23). Although the effect of bleomycin on $\mathrm{PGE}_{2}$ release has not been studied in fibroblasts, Clark et al. have shown that mac-

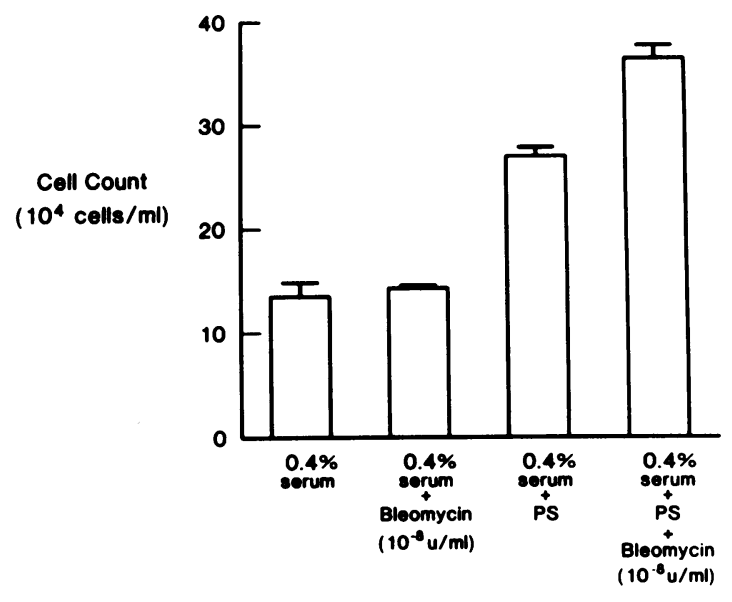

Figure 4. Fibroblast proliferation in response to PS (1:6 dilution) and bleomycin, as measured by actual cell counts. Fibroblasts were plated at a concentration of $4 \times 10^{4}$ cells $/ \mathrm{ml}$ in medium plus $0.4 \%$ serum, and then incubated with either $0.4 \%$ serum alone, $0.4 \%$ serum plus bleomycin $\left(10^{-8} \mathrm{U} / \mathrm{ml}\right), 0.4 \%$ serum plus PS (1:6 dilution), or $0.4 \%$ serum plus bleomycin and PS. The cells were then removed from the plate and counted using a hemocytometer. The data represent the mean \pm SEM of three separate studies. 


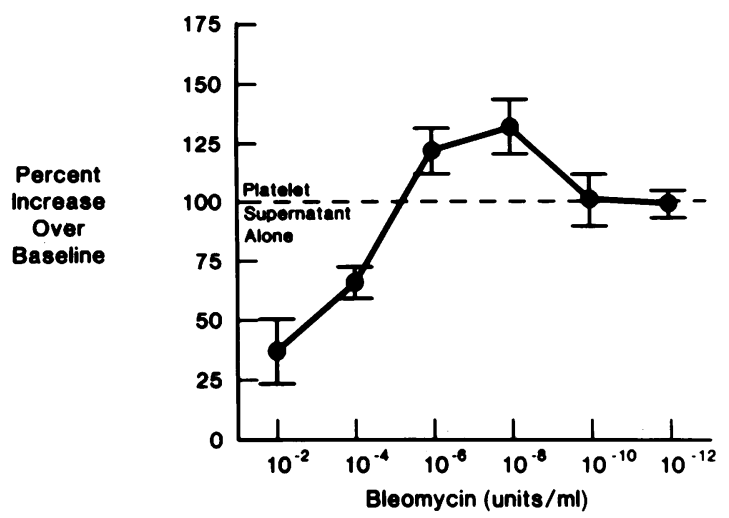

Figure 5. Fibroblast proliferation in response to PS (1.6 dilution) and amounts of bleomycin from $10^{-2}$ to $10^{-12} \mathrm{U} / \mathrm{ml}$. The cells were plated at a concentration of $4 \times 10^{4} \mathrm{cells} / \mathrm{ml}$ in medium plus $0.4 \%$ serum, and then incubated in medium alone or PS plus various amounts of bleomycin. At the end of incubation, the fibroblasts were pulsed with $\left[{ }^{3} \mathrm{H}\right]$ thymidine. Incorporation of $\left[{ }^{3} \mathrm{H}\right]$ thymidine was used as an index of cell proliferation ( $100 \%$ growth is equal to $\left[{ }^{3} \mathrm{H}\right]$ thymidine incorporation by cells exposed to PS alone). The data represent the mean \pm SEM of six separate studies.

rophages exposed to bleomycin secrete markedly decreased amounts of $\mathrm{PGE}_{2}$ (24-25). In their model system, this decrease of $\mathrm{PGE}_{2}$ production is associated with fibroblast proliferation and increased fibrosis. These observations and those of the present study suggest that bleomycin might cause fibroblast proliferation by inhibiting not only $\mathrm{PGE}_{2}$ production by fibroblasts but also $\mathrm{PGE}_{2}$ production by other cells in the environment of the fibroblast.

The results of these studies can also be directly related to the doses of bleomycin used for chemotherapy. In this regard, pharmacologic studies of bleomycin given by intravenous infusion have determined that patients receiving $30 \mathrm{U} / \mathrm{d}$ attain a mean peak plasma level of $2 \times 10^{-4} \mathrm{U} / \mathrm{ml}$ (26). Initial elimination is rapid, but after $12 \mathrm{~h}$ the elimination rate changes to a beta half-life of $8.9 \mathrm{~h}(26)$. Regression analysis reveals an elimination rate constant $(K)$ of $7.8 \times 10^{-2} \mathrm{~h}^{-1}$. Using a standard elimination half-life equation, $C p=\left(C p_{1}\right)\left(\mathrm{e}^{-K t}\right)$, where $C p$ is the plasma concentration at time of interest, $C p_{1}$ is the plasma concentration at time 0 and $t$ is the hours from time 0 , it can be estimated that bleomycin would be present in plasma at levels $>10^{-9} \mathrm{U} / \mathrm{ml}$ for $\sim 126 \mathrm{~h}$. These observations suggest that chemotherapeutic regimens that use bleomycin on a weekly basis will expose patients to levels of bleomycin that augment fibroblast proliferation and injure endothelial cells for up to $5 \mathrm{~d}$ after each dose throughout the course of treatment. In patients with impaired renal function, bleomycin clearance would be prolonged four- to fivefold for a plasma concentration of $>10^{-9} \mathrm{U} / \mathrm{ml}$ for $500 \mathrm{~h}$ postinfusion. If the results of this study can be related to the in vivo effects of bleomycin, then patients are exposed to concentrations of the drug that cause injury to endothelial cells and possibly other lung cells for a prolonged period of time. Fibroblasts, however, may not only be unharmed by these doses of bleomycin but may also be stimulated to increase their cell growth in response to various growth factors generated in the environment of the fibroblast in response to the injury of endothelial cells.

\section{Acknowledgments}

The authors thank Fernie Hampson, Charles Dayton, and Vanessa Krumbholz for technical assistance, and Bristol Laboratories for their donation of the bleomycin used in these studies.

These studies were supported by grants from the Veterans Administration and National Institutes of Health grants 1-R03-04081-5601 and 1-R01 HL29438-01A1.

\section{References}

1. Jones, A. W. 1978. Bleomycin lung damage: the pathology and nature of the lesion. Br. J. Dis. Chest. 72:321-326.

2. Fahey, P. J., M. J. Utell, R. J. Mayewski, J. D. Wandtke, and R. W. Hyde. 1982. Early diagnosis of bleomycin pulmonary toxicity using bronchoalveolar lavage in dogs. Am. Rev. Respir. Dis. 126:126130.

3. Adamson, I. Y. R., and D. H. Bowden. 1974. The pathogenesis of bleomycin-induced pulmonary fibrosis in mice. Am. J. Pathol. 77: 185-198.

4. Catravas, J. D., J. S. Lazo, and C. N. Gillis. 1981. Biochemical markers of bleomycin toxicity: clearance of $\left[{ }^{14} \mathrm{C}\right]-5$-hydroxytryptamine and $\left[{ }^{3} \mathrm{H}\right]$-norepinephrine by rabbit lung in vivo. J. Pharmacol. Exp. Ther. 217:524-529.

5. Goldstein, R. H., E. C. Lucey, C. Franzblau, and G. L. Snider. 1979. Failure of mechanical properties to parallel changes in lung connective tissue composition in bleomycin-induced pulmonary fibrosis in hamsters. Am. Rev. Respir. Dis. 120:67-73.

6. Thrall, R. S., J. E. McCormick, R. M. Jack, R. A. McReynolds, and P. A. Ward. 1979. Bleomycin-induced pulmonary fibrosis in the rat. Am. J. Pathol. 95:117-130.

7. Collins, J. F., B. McCullough, J. J. Coalson, and W. G. Johanson. 1981. Bleomycin-induced diffuse interstitial fibrosis in baboons. $\mathrm{Am}$. Rev. Respir. Dis. 123:305-312.

8. Ross, R., and A. Vogel. 1978. The platelet-derived growth factor. Cell. 14:203-210.

9. Scher, C. D., R. C. Shepard, H. N. Antoniades, and C. D. Stiles. 1979. Platelet-derived growth factor and the regulation of the mammalian fibroblast cell cycle. Biochem. Biophys. Acta. 560:217-241.

10. Johnson, A. R., and E. G. Erdos. 1977. Metabolism of vasoactive peptides by human endothelial cells in culture. J. Clin. Invest. 59:684695.

11. Bradley, K. H., O. Kawanami, V. J. Ferrans, and R. G. Crystal. 1980. The fibroblast of human lung alveolar structures: a differentiated cell with a major role in lung structure and function. Methods Cell Biol. 21A:37-64.

12. Moseley, P. L., D. M. Shasby, M. Brady, and G. W. Hunninghake. 1984. Lung parenchymal injury induced by bleomycin. Am. Rev. Respir. Dis. 130:1082-1086.

13. Takeshita, M., A. P. Grollman, E. Ohtsubo, and H. Ohtsubo. 1978. Interaction of bleomycin with DNA. Proc. Natl. Acad. Sci. USA. 75:5983-5987.

14. Povirk, L. F., M. Hogan, and N. Dattagupta. 1979. Binding of bleomycin to DNA: intercalation of the bithiazole rings. Biochemistry. 18:96-101.

15. Chien, M., A. P. Grollman, and S. B. Horowitz. 1977. BleomycinDNA interaction: fluorescence and proton resonance studies. Biochemistry. 16:3641-3647.

16. Absher, M., J. Hildebran, L. Trombley, J. Woodstock-Mitchell, and J. Marsh. 1984. Characteristics of cultured lung fibroblasts from bleomycin-treated rats. Am. Rev. Respir. Dis. 129:125-129.

17. Passero, M. A., J. K. Held, and P. M. Shearer. 1983. Effects of bleomycin, $\mathrm{O}_{2}$ concentration, and $\mathrm{H}_{2} \mathrm{O}_{2}$ on peroxidation of arachidonic acid. Am. Rev. Respir. Dis. 127:287a. (Abstr.) 
18. Giri, S. N., Z. L. Chen, W. R. Younker, and M. J. Schiedt. 1983. Effects of intratracheal administration of bleomycin on GSH-shuttle enzymes, catalase, lipid peroxidation, and collagen content in the lungs of hamsters. Toxicol. Appl. Pharmacol. 71:132-141.

19. Barranco, S. C., J. K. Novak, and R. M. Humphrey. 1975. Studies on recovery from chemically induced damage in mammalian cells. Cancer Res. 35:1194-1204.

20. Igbal, A. M., K. W. Korn, R. A. Ewig, and A. J. Fornace. 1976. Single-strand scission and repair of DNA in mammalian cells by bleomycin. Cancer Res. 36:3834-3840.

21. Bourne, H., and E. Rozengurt. 1976. An 18,000 molecular weight polypeptide induces early events and stimulates DNA synthesis in cultured cells. Proc. Natl. Acad. Sci. USA. 73:4555-4559.
22. Mierzejewski, K., and E. Rozengurt. 1978. Density-dependent inhibition of fibroblast growth is overcome by pure mitogenic factors. Nature (Lond.). 269:155-156.

23. Korn, J. H. 1983. Fibroblast prostaglandin $\mathrm{E}_{2}$ synthesis. J. Clin. Invest. 71:1240-1246.

24. Clark, J. G., K. M. Kostal, and B. A. Marino. 1982. Modulation of collagen production following bleomycin-induced pulmonary fibrosis in hamsters. J. Biol. Chem. 257:8098-8105.

25. Clark, J. G., K. M. Kostal, and B. A. Marino. 1983. Bleomycininduced pulmonary fibrosis in hamsters. J. Clin. Invest. 72:2082-2091.

26. Broughton, A., J. E. Strong, P. Y. Holoye, and C. W. M. Bedrossian. 1977. Clinical pharmacology of bleomycin following intravenous infusion as determined by radioimmunoassay. Cancer. 40:27722778. 